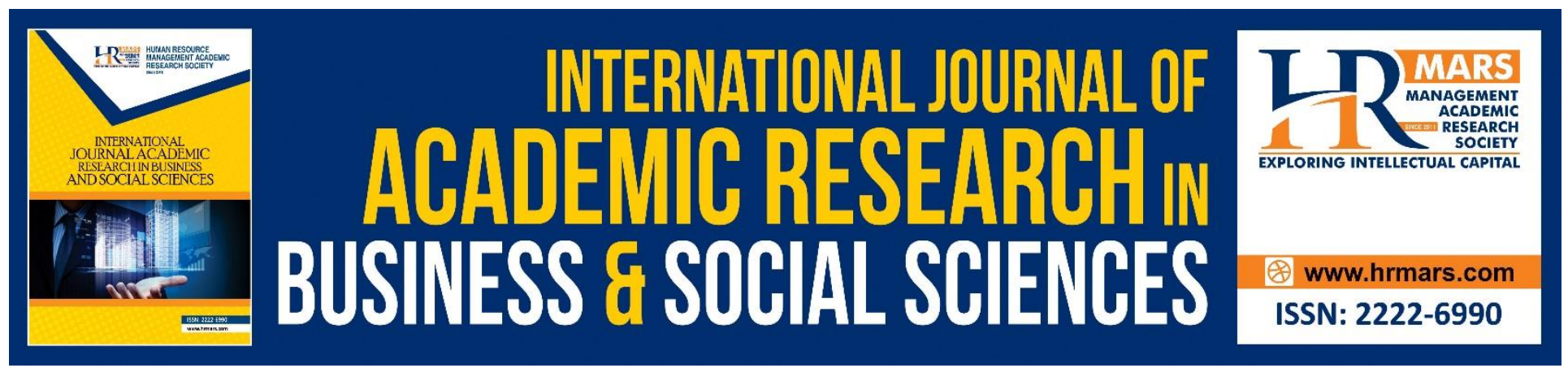

\title{
Teachers' Knowledge in English for Communication (EFC) Teaching of Elementary Vocational Education (PAV) Program
}

\author{
Najihah Abd Wahid, Nur Azwa Zynuddin, Anas Mohd Yunus
}

To Link this Article: http://dx.doi.org/10.6007/IJARBSS/v8-i10/4735

DOI: $10.6007 /$ IJARBSS/v8-i10/4735

Received: 15 Sept 2018, Revised: 13 Oct 2018, Accepted: 16 Oct 2018

Published Online: 31 October 2018

In-Text Citation: (Wahid, Zynuddin, \& Yunus, 2018)

To Cite this Article: Wahid, N. A., Zynuddin, N. A., \& Yunus, A. M. (2018). Teachers' Knowledge in English for Communication (EFC) Teaching of Elementary Vocational Education (PAV) Program. International Journal of Academic Research in Business and Social Sciences, 8(10), 300-307.

\section{Copyright: (C) 2018 The Author(s)}

Published by Human Resource Management Academic Research Society (www.hrmars.com)

This article is published under the Creative Commons Attribution (CC BY 4.0) license. Anyone may reproduce, distribute, translate and create derivative works of this article (for both commercial and non-commercial purposes), subject to full attribution to the original publication and authors. The full terms of this license may be seen

at: http://creativecommons.org/licences/by/4.0/legalcode

Vol. 8, No. 10, 2018, Pg. 300 - 307

http://hrmars.com/index.php/pages/detail/IJARBSS

JOURNAL HOMEPAGE

Full Terms \& Conditions of access and use can be found at http://hrmars.com/index.php/pages/detail/publication-ethics 


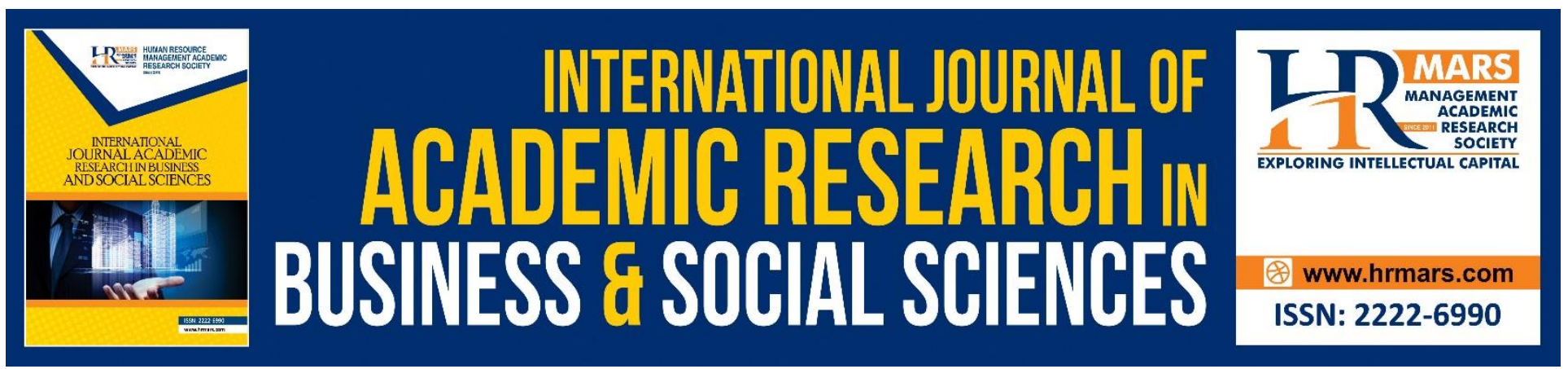

\title{
Teachers' Knowledge in English for Communication (EFC) Teaching of Elementary Vocational Education (PAV) Program
}

\author{
Najihah Abd Wahid, Nur Azwa Zynuddin, Anas Mohd Yunus \\ Universiti Sultan Zainal Abidin (UniSZA), Kampus Gong Badak, 21300 Kuala Terengganu \\ Terengganu, Malaysia \\ Email: nurazwazynuddin@yahoo.com
}

\begin{abstract}
The purpose of this study was to identify the extent of teachers' knowledge towards teachers' efficiency in teaching English for Communication (EFC) subject of Elementary Vocational Education (PAV) program. A random sampling which consisted of 66 EFC teachers from 79 secondary schools offered the PAV program nationwide. The study adopted a survey-based non experimental research design. A set of questionnaire was set up and the items used in this study were developed based on Shulman's Model of Pedagogical Reasoning and Action (1987). Descriptive analysis was applied to test and the data were analyzed using the SPSS software version 21 . The findings of descriptive analysis are to obtain the mean and the respondents' demography along the data of the extent of teachers' knowledge in EFC teaching. The research of the extent of teachers' knowledge has been conducted in a few elements such as comprehension, application, emphasis in EFC teaching, and professional development in EFC teaching of PAV program.
\end{abstract}

Keywords: Teachers' Knowledge, EFC, PAV Program

\section{INTRODUCTION}

Education plays a crucial role in developing quality human capital in terms of creative, critical, analytical and critical thinking. The ability to solve problems and to have high endurance in the global challenges will produce human capital to have a strong identity, competent, honourable, knowledgeable and highly skilled. Malaysian Education Blueprint (PPPM) 2013-2025 has outlined that education is in need of new changes and its implementation should be modified as to meet new demands in the education sector. The success of a lesson depends on how a teacher handles the class effectively and will always be an inspiration to all students (Ibrahim, 2013 and Azreen, 2011).

Teaching profession is imperative which needs a long-term commitment and the teachers should be consisted of those who are strong-spirited and ready to adapt the changes. Many previous 
studies have shown a lack of effective teachers in the teaching process causing a lack of students who are interested in learning. Preparing students with the skills and knowledge required to function properly where the activities and tasks are undertaken by teachers and students to develop quality knowledge and gain effective knowledge (Saharia, 2015; Haliza,2014; Ismail,2013; Saedah \& Sani; Noriati, Boon and Sharifah (2012) and Hisham, 2011).

For the empowerment of TVE, Ministry of Education (KPM) has embarked on the Transformation of Vocational Education in 2010. An action set out in the strategic transformation plan is to establish elementary vocational education program (PAV). The main goal of PAV is to attract former primary school students who have interest in vocational education to choose PAV program other than mainstream academic program. The offer of PAV program aims to produce workforce and entrepreneurs who are accepted by the job market. As of 2017, fifteen State Education Department (JPN) are involved in the PAV program, which cover a total of 81 secondary schools throughout Malaysia (Zainureen, 2016; KPM, 2015; Faridah, 2014; Noor, 2013).

The PAV program is based on the ability and competence of students. The curriculum structure of the PAV program requires teachers to teach students to be competent in the subjects they studied. The teacher will have to repeat teaching the same topic until the students are competent if the students have not mastered the topic learned. However, if the teacher wishes to continue teaching a new topic although there are still students who have not mastered the previous topics, the teacher can use their creativity in two ways. They can asks students who have mastered the topic to help their friends who have not, or the teacher gives a more difficult exercise to students who have mastered the given topic. After all students have mastered the topic, the teacher can proceed with a new topic (KPM, 2015).

English for Communication (EFC) is a subject that is introduced in PAV program. In the PAV curriculum structure, EFC is under the communication dimension in which it is introduced with the primary aim to produce PAV graduates who are skilled in listening, reading, writing and speaking in English language. The implementation of EFC is adapted to the function of the PAV program which is students' competency-based. PAV students need to be competent or master language, communication, knowledge, information, ideas, skills and values to meet KPM's target in producing students who are able work and well-received in the job market, and able to use the skills they have acquired in their daily lives. In addition, EFC is one of the processes in the student-centered pedagogical approach to create awareness among PAV students in maintaining their interest to continue communicating in English (KPM, 2015).

\section{RESEARCH METHODOLOGY}

This study used quantitative approach. For this paper, the discussion is based on the data collected using a questionnaire. A random sampling of teachers was employed nationwide. A total of 81 survey questionnaires were distributed by using Google Form and Whatsapp through smartphones and 66 were returned (a return rate of $82 \%$ ). The responses given by the respondents were collected and later analysed using SPSS (Statistical Package for Social Sciences version 21.0). Data was analysed using frequencies and percentages. The respondents for the study are 66 EFC PAV secondary school 
INTERNATIONAL JOURNAL OF ACADEMIC RESEARCH IN BUSINESS AND SOCIAL SCIENCES Vol. 8, No. 10, Oct. 2018, E-ISSN: 2222-6990 @ 2018 HRMARS

teachers. In terms of subject matter expertise, 59\% are English language teachers while $41 \%$ are nonoption English teachers, engineering and others. Table 1 illustrates the details of the respondents' type of employment.

Table 1: Type of Employment

\begin{tabular}{|l|l|l|}
\hline Type of Employment & Frequency & Percentage (\%) \\
\hline Engineering option teacher & 4 & 6.0 \\
\hline English option teacher & 39 & 59.0 \\
\hline Non English option teacher & 13 & 20.0 \\
\hline Others & 10 & 15.0 \\
\hline Total & 66 & 100.0 \\
\hline
\end{tabular}

\section{FINDINGS AND DISCUSSION}

The focus of the paper is on the teachers' knowledge in EFC teaching of PAV program. Shulman (1987) used Model of Pedagogical Reasoning and Action (MPRA) which consist of six components such as comprehension, transformation, instruction, evaluation, reflection and new idea. In this study, MPRA remodelled by using the three main components. They are comprehension, instruction and reflection. In the following, the analysis of teaching aspects such as comprehension, application, emphasis in EFC teaching, and professional development in EFC teaching of PAV program will be discussed. For knowledge in teaching EFC for PAV, teachers are asked their comprehension of EFC subject. The findings showed that 28 teachers (42.4\%) from all the respondents were less agreed on the content of the subject. About 34 respondents (51.5\%) also responded less agreed on the EFC management subject, 33 respondents (50\%), 29 respondents (43.9\%) and 35 respondents (53\%) less agreed that they have a clear understanding of the EFC subject in methodology used, the importance of EFC subject with PAV students' daily life and the current issue of the subject. Based on the details in Table 2, it can be said that these teachers are moderately understand of the EFC subject for PAV program classes which represent mean is 3.33 .

\begin{tabular}{|c|c|c|c|c|c|}
\hline \multirow{2}{*}{ Content } & \multicolumn{5}{|c|}{ Frequency (respondent) } \\
\hline & DS & DA & LA & $\mathbf{A}$ & SA \\
\hline The content of EFC subject & $\begin{array}{l}3 \\
(4.5 \%)\end{array}$ & $\begin{array}{l}5 \\
(7.6 \%)\end{array}$ & $\begin{array}{l}28 \\
(42.4 \%)\end{array}$ & $\begin{array}{l}20 \\
(30.3 \%)\end{array}$ & $\begin{array}{l}4 \\
(15.2 \%)\end{array}$ \\
\hline EFC Management subject & $\begin{array}{l}2 \\
(3.0)\end{array}$ & $\begin{array}{l}5 \\
(7.6 \%) \\
\end{array}$ & $\begin{array}{l}34 \\
(51.5 \%)\end{array}$ & $\begin{array}{l}18 \\
(27.3 \%\end{array}$ & $\begin{array}{l}7 \\
(10.6 \%)\end{array}$ \\
\hline The methodology used in EFC subject & $\begin{array}{l}3 \\
(4.5 \%)\end{array}$ & $\begin{array}{l}4 \\
(6.1 \%)\end{array}$ & $\begin{array}{l}33 \\
(50 \%)\end{array}$ & $\begin{array}{l}20 \\
(30.3 \%)\end{array}$ & $\begin{array}{l}6 \\
(9.1 \%)\end{array}$ \\
\hline The importance of EFC subject with PAV students' daily life & $\begin{array}{l}1 \\
(1.5 \%)\end{array}$ & $\begin{array}{l}5 \\
(7.6 \%)\end{array}$ & $\begin{array}{l}29 \\
(43.9 \%)\end{array}$ & \begin{tabular}{|l}
18 \\
$(27.3 \%)$
\end{tabular} & $\begin{array}{l}13 \\
(19.7 \%)\end{array}$ \\
\hline The current issue of EFC subject & $\begin{array}{l}4 \\
(6.1 \%)\end{array}$ & $\begin{array}{l}11 \\
(16.7 \%)\end{array}$ & $\begin{array}{l}35 \\
(53.0 \%)\end{array}$ & $\begin{array}{l}14 \\
(21.2 \%)\end{array}$ & $\begin{array}{l}2 \\
(3.0 \%)\end{array}$ \\
\hline Mean & 3.33 & & & & \\
\hline
\end{tabular}

Table 2: Comprehension of EFC subject in PAV Program 
INTERNATIONAL JOURNAL OF ACADEMIC RESEARCH IN BUSINESS AND SOCIAL SCIENCES Vol. 8, No. 10, Oct. 2018, E-ISSN: 2222-6990 @ 2018 HRMARS

For the application of PAV lesson plan during EFC teaching, majority of the respondents indicated that they were moderately apply the PAV lesson plan. The result showed that 28 respondents (42.4\%) are not familiar with PAV lesson plan, 31 respondents (47\%) are not writing EFC PAV daily lesson plans correctly, 26 respondents (39.4\%) are not writing PAV learning objectives in PAV lesson plan, 3030 respondents $(45.5 \%)$ are not using a variety of materials related to PAV during EFC lesson, and 36 respondents (54.5\%) are not using different forms of assessment accordance to students' competencies in their lesson plans. The mean is 3.47 which stated the application of PAV lesson plan during EFC teaching among the teachers are temperate and this is probably attributed to the teachers' lack of confidence teaching English for PAV program classes. Table 3 illustrates the analysis of the teachers' application of PAV lesson plan during EFC teaching.

\section{Table 3: Application of PAV Lesson Plan during EFC Teaching}

\begin{tabular}{|c|c|c|c|c|c|}
\hline Content & DS & DA & LA & A & SA \\
\hline I am familiar with PAV lesson plan & $\begin{array}{l}4 \\
(6.1 \%)\end{array}$ & $\begin{array}{l}7 \\
(10.6)\end{array}$ & $\begin{array}{l}28 \\
(42.4 \%)\end{array}$ & $\begin{array}{l}21 \\
(31.8)\end{array}$ & $\begin{array}{l}6 \\
(9.1 \%)\end{array}$ \\
\hline I write EFC PAV daily lesson plans correctly & $\begin{array}{l}2 \\
(3.0 \%)\end{array}$ & $\begin{array}{l}4 \\
(6.1 \%)\end{array}$ & $\begin{array}{l}31 \\
(47 \%)\end{array}$ & $\begin{array}{l}22 \\
(33.3 \%)\end{array}$ & $\begin{array}{l}7 \\
(10.6 \%)\end{array}$ \\
\hline I write PAV learning objectives in PAV lesson plan & $\begin{array}{l}1 \\
(1.5 \%)\end{array}$ & $\begin{array}{l}3 \\
(4.5 \%)\end{array}$ & $\begin{array}{l}26 \\
(39.4 \%)\end{array}$ & $\begin{array}{l}21 \\
(31.8 \%)\end{array}$ & $\begin{array}{l}15 \\
(22.7 \%)\end{array}$ \\
\hline I use a variety of materials related to PAV during EFC lesson & $\begin{array}{l}1 \\
(1.5 \%)\end{array}$ & 3 & $\begin{array}{l}30 \\
(45.5 \%)\end{array}$ & $\begin{array}{l}21 \\
(31.8 \%)\end{array}$ & $\begin{array}{l}11 \\
(16.7 \%)\end{array}$ \\
\hline $\begin{array}{l}\text { I use different forms of assessment accordance to students' } \\
\text { competencies in my lesson plan }\end{array}$ & $\begin{array}{l}1 \\
(1.5 \%)\end{array}$ & $\begin{array}{l}3 \\
(4.5 \%)\end{array}$ & $\begin{array}{l}36 \\
(54.5 \%)\end{array}$ & $\begin{array}{l}20 \\
(30.3 \%)\end{array}$ & $\begin{array}{l}6 \\
(9.1 \%)\end{array}$ \\
\hline Mean & 3.47 & & & & \\
\hline
\end{tabular}

The questionnaire also examined how teachers relate the students' competencies in their teaching. For the emphasis of teaching EFC in PAV program classrooms, the findings showed that teachers were able to emphasize the goal of teaching PAV in their EFC teaching when 26 respondents (39.4\%) agreed, 27 respondents (40.9\%) and 28 respondents (42.4\%) teach materials accordance to students' interest and abilities. However, 30 respondents (45.5\%) are not emphasize the PAV teaching strategies in their teaching, and 27 respondents (40.9\%) are not doing the PAV assessments based on students' competencies. Looking at the mean 3.41, it can be explain that the teachers are not fully emphasizing of teaching EFC for PAV students. Table 4 provided the details of the analysis. 
INTERNATIONAL JOURNAL OF ACADEMIC RESEARCH IN BUSINESS AND SOCIAL SCIENCES Vol. 8, No. 10, Oct. 2018, E-ISSN: 2222-6990 @ 2018 HRMARS

Table 4: Emphasis of Teaching EFC for PAV students

\begin{tabular}{|c|c|c|c|c|c|}
\hline \multirow{2}{*}{ Content } & \multicolumn{5}{|c|}{ Frequency (respondent) } \\
\hline & DS & DA & LA & A & SA \\
\hline The goal of teaching PAV & $\begin{array}{l}2 \\
(3.0 \%)\end{array}$ & $\begin{array}{l}6 \\
(9.1 \%)\end{array}$ & $\begin{array}{l}26 \\
(39.4 \%)\end{array}$ & $\begin{array}{l}26 \\
(39.4 \%)\end{array}$ & $\begin{array}{l}6 \\
(9.1 \%)\end{array}$ \\
\hline PAV teaching strategies (TS) & $\begin{array}{l}1 \\
(1.5 \%)\end{array}$ & $\begin{array}{l}9 \\
(13.6 \%)\end{array}$ & $\begin{array}{l}30 \\
(45.5 \%)\end{array}$ & $\begin{array}{l}20 \\
(30.3 \%)\end{array}$ & $\begin{array}{l}6 \\
(9.1 \%)\end{array}$ \\
\hline $\begin{array}{l}\text { Teaching materials are accordance to students } \\
\text { interest }\end{array}$ & $\begin{array}{l}4 \\
(6.1 \%)\end{array}$ & $\begin{array}{l}4 \\
(6.1 \%)\end{array}$ & $\begin{array}{l}25 \\
(37.9 \%)\end{array}$ & $\begin{array}{l}27 \\
(40.9 \%)\end{array}$ & $\begin{array}{l}6 \\
(9.1 \%)\end{array}$ \\
\hline $\begin{array}{l}\text { Teaching materials are accordance to students } \\
\text { abilities }\end{array}$ & $\begin{array}{l}2 \\
(3.0 \%) \\
\end{array}$ & $\begin{array}{l}4 \\
(6.1 \%) \\
\end{array}$ & $\begin{array}{l}25 \\
(37.9 \%)\end{array}$ & $\begin{array}{l}28 \\
(42.4 \%)\end{array}$ & $\begin{array}{l}7 \\
(10.6 \%)\end{array}$ \\
\hline $\begin{array}{l}\text { PAV assessment applied based on students } \\
\text { competency }\end{array}$ & $(1.5 \%)$ & 9 & $\begin{array}{l}27 \\
(40.9 \%)\end{array}$ & $\begin{array}{l}22 \\
(33.3 \%)\end{array}$ & $\begin{array}{l}7 \\
(10.6 \%)\end{array}$ \\
\hline Mean & 3.41 & & & & \\
\hline
\end{tabular}

Teachers also moderately agreed that not many of them use the items asked for their professional development enhancement. This is because the mean accumulated is 3.45 and 23 respondents (34.8\%) are not thinking reflectively before teaching, 33 respondents (30\%) and 32 respondents (48.5\%) do not talking to PAV colleagues before and after teaching, 26 respondents (39.4\%) are not adding general knowledge by reading other sources and 29 respondents $(43.9 \%)$ are not engaging with courses and seminars where necessary. However, 23 respondents (34.8\%) agreed they do reflection after teaching and 25 respondents (37.9\%) adding knowledge about their teaching by reading other sources. Table 5 illustrated the analysis of teacher's professional development in EFC teaching for PAV program.

Table 5: Professional Development

\begin{tabular}{|c|c|c|c|c|c|}
\hline \multirow{2}{*}{ Content } & \multicolumn{5}{|c|}{ Frequency (respondent) } \\
\hline & DS & DA & LA & A & SA \\
\hline Think reflectively before teaching & $\begin{array}{l}1 \\
(1.5 \%)\end{array}$ & $\begin{array}{l}5 \\
(7.6 \%)\end{array}$ & $\begin{array}{l}23 \\
(34.8 \%)\end{array}$ & $\begin{array}{l}22 \\
(33.3 \%)\end{array}$ & \begin{tabular}{|l}
15 \\
$(22.7 \%)$
\end{tabular} \\
\hline Talk to PAV colleagues before teaching & $\begin{array}{l}2 \\
(3.0 \%) \\
\end{array}$ & $\begin{array}{l}11 \\
(16.7 \%)\end{array}$ & $\begin{array}{l}33 \\
(50.0 \%)\end{array}$ & $\begin{array}{l}12 \\
(18.2 \%)\end{array}$ & $\begin{array}{l}8 \\
(12.1 \%)\end{array}$ \\
\hline Reflection after teaching & $\begin{array}{l}2 \\
(3.0 \%)\end{array}$ & $\begin{array}{l}4 \\
(6.1 \%)\end{array}$ & $\begin{array}{l}23 \\
(34.8 \%)\end{array}$ & $\begin{array}{l}23 \\
(34.8 \%)\end{array}$ & $\begin{array}{l}14 \\
(21.2 \%)\end{array}$ \\
\hline Talk to PAV colleagues after teaching & $\begin{array}{l} \\
(3.0 \%)\end{array}$ & $\begin{array}{l}10 \\
(15.2 \%)\end{array}$ & $\begin{array}{l}32 \\
(48.5 \%)\end{array}$ & $\begin{array}{l}17 \\
(25.8 \%)\end{array}$ & \begin{tabular}{|l}
5 \\
$(7.6 \%)$
\end{tabular} \\
\hline Adding knowledge about my teaching by reading other sources & $\begin{array}{l}1 \\
(1.5 \%)\end{array}$ & $\begin{array}{l}6 \\
(9.1 \%)\end{array}$ & $\begin{array}{l}22 \\
(33.3 \%)\end{array}$ & $\begin{array}{l}25 \\
(37.9 \%)\end{array}$ & $\begin{array}{l}12 \\
(18.2 \%)\end{array}$ \\
\hline Adding my general knowledge by reading other sources & $\begin{array}{l}1 \\
(1.5 \%)\end{array}$ & $\begin{array}{l}3 \\
(4.5 \%)\end{array}$ & $\begin{array}{l}26 \\
(39.4 \%)\end{array}$ & $\begin{array}{l}23 \\
(34.8 \%)\end{array}$ & $\begin{array}{l}13 \\
(19.7 \%)\end{array}$ \\
\hline Engaging with courses and seminars where necessary & $\begin{array}{l}5 \\
(7.6 \%) \\
\end{array}$ & $\begin{array}{l}10 \\
(15.2 \%)\end{array}$ & $\begin{array}{l}29 \\
(43.9 \%)\end{array}$ & $\begin{array}{l}17 \\
(25.8 \%)\end{array}$ & $\begin{array}{l}5 \\
(7.6 \%)\end{array}$ \\
\hline Mean & 3.45 & & & & \\
\hline
\end{tabular}




\section{CONCLUSION}

This study aims to gain teachers' knowledge of EFC teaching in PAV program. The findings reported in this study revealed that there are many challenges faced by EFC teachers when implementing EFC teaching in PAV program. In this study, the teachers are not well equipped with the subject matter content of EFC in PAV Program. PAV is a program to prevent dropouts from former primary school students who have less inclination towards academic and it is also a new program introduced by KPM since 2012 (KPM, 2015). Attention should be given to EFC teachers to ensure that they employ effective teaching practices to PAV students. Teachers are well-known as important agents of knowledge and this study highlight the need to provide EFC teachers development opportunities in PAV program. Advance courses are also important for all EFC teachers who teach PAV classes. Courses related to class management for academic teachers, such as EFC teachers, are essential for teachers to enhance their knowledge in carrying out the teaching process on the basis of PAV program concept set by KPM. Additionally, teachers who teach EFC subject should at least have foundation in English language and engineering options (Anuar, 2016). If the EFC teachers did not have both, intensive courses should be carried out to ensure the smoothness of the PAV program in line with the views of Derek Cheung, Zohar, Degani and Vaaknin (2001) whereby they noted that many attempts in educational changes have failed because the mastery of subject content taught, teaching strategies in classroom and the skills in mastering technology among teachers that do not reach the required level.

\section{Acknowledgement}

Special thanks to the Research Management, Innovation and Commercialization Centre (RMIC), Universiti Sultan Zainal Abidin.

\section{References}

Anuar, M. S. (2016). Bahagian Pembangunan Kurikulum (BPK), Kementerian Pelajaran Malaysia (KPM) Putrajaya.

Cheung,D. (2001). School-based Assessment in Public Examinations: Identifying The Concerns of Teachers. Educational Journal, 29(2).

Mariani, J.F (2014). Isu dan Cabaran Pelaksanaan Pendidikan AsasVokasional (PAV) di Sekolah Menengah Harian. Proceeding of Teaching And Learning In The 21st Century: Challenges for Lecturers and Teachers, 98-106.

Mariani, J.F (2014). Isu dan Cabaran Pelaksanaan Pendidikan Asas Vokasional (PAV) di Sekolah Menengah Harian. Proceeding of Teaching And Learning In The 21st Century: Challenges for Lecturers and Teachers, 98-106.

Haliza, H., \& Samuel, J. N. (2014). Pengurusan Bilik Darjah Dan Tingkah Laku (Siri Pendidikan Guru). Kuala Lumpur: Penerbit Oxford Fajar Sdn. Bhd, 1-249.

Kementerian Pelajaran Malaysia (2014). Apa Yang Anda Ingin Tahu Tentang Kolej Vokasional? 1.

Kementerian Pelajaran Malaysia (2014). Panduan pelaksanaan kurikukum: PAV di sekolah menengah harian, tingkatan 1 hingga 3. Wilayah Persekutuan Putrajaya: Bahagian Pembangunan Kurikulum. 
INTERNATIONAL JOURNAL OF ACADEMIC RESEARCH IN BUSINESS AND SOCIAL SCIENCES

Vol. 8, No. 10, Oct. 2018, E-ISSN: 2222-6990 @ 2018 HRMARS

Kementerian Pelajaran Malaysia (2015). Panduan pelaksanaan kurikukum: PAV di sekolah menengah harian, tingkatan 1 hingga 3. Wilayah Persekutuan Putrajaya: Bahagian Pembangunan Kurikulum.

Azreen, A. A.N. (2011). Pentaksirana Iternatif: Menuju kearah transformasi system pentaksiran di Malaysia. Proceedings of The National Conference On Research And Innovation In Education And Technical And Vocational Training. 616-623.

Hisham, M. N.N. (2011). Pengajaran dan Pembelajaran; Penetitian Semula Konsep-Konsep Asas Menurut Perspektif Gagasan Islamisasi Ilmu Moden. Kongres Pengajaran dan Pembelajaran UKM 2011. 4

Hisham, M. N.N. (2011).Pengajaran dan Pembelajaran; Penetitian Semula Konsep-Konsep Asas Menurut Perspektif Gagasan Islamisasi IImu Moden. Kongres Pengajaran dan Pembelajaran UKM 2011, 4

Hasliza, M.N. (2012). Penglibatan Pelajar Dalam Pembelajaran Koperatif Di Sekolah Menengah Vokasional. Retrieved from http://eprints.Uthm.Edu.My/.../Nor Hasliza Binti Mohamed.Pdf

Noraini, I., Hanie,A., A. A., \& Radha M. K. N. (2013). Expertise in the Classroom: The Multiple Roles of Master Teachers in Malaysia.

Panduan Pelaksanaan Kurikulum (2015). Pendidikan Asas Vokasional (PAV) Di Sekolah Menengah Harian Dan Sekolah Komprehensif 9 (K9), Tingkatan Satu Hingga Tiga. Kementerian Pelajaran Malaysia (KPM) Putrajaya.

Saedah, S., \& Mohammed Sani, I. (2012). Standard Kompetensi Guru Malaysia. Prosiding Seminar Kebangsaan Majlis Dekan Pendidikan Malaysia.

Saharia, I. (2015) Pembangunan Insan Dalam Falsafah Pendidikan Kebangsaan. Journal of Human Capital Development, 8(2); 83-101.

Shulman, L. S. (1987). Knowledge and Teaching: Foundations of the New Reform. Harvard Educational Review, 57; 1-22.

Ainsyah,S.N, I. (2015). Penguasaan Teknik Kemahiran Fasilitator Dalam Pelaksanaan Pembelajaran Berpusatkan Pelajar Di Universiti Tun Hussein Onn Malaysia.

Ismail, S. M.S, \& Ahmad Subki, M. (2013). Guru dan Cabaran Semasa. Selangor: Penerbitan Multimedia Sdn. Bhd, 2; 1-249

Zainuren, H. M. N. (2016). Transformasi Pendidikan Teknik dan Vokasional Analisis. Astro Awani, Retrieved from http://www.astroawani.com/video-malaysia/analisis-awani-transformasipendidikan-teknik-dan-vokasional-123874

Zamri, M. (2004). Strategi Pembelajaran Bahasa Melayu Pelajar Cemerlang Sekolah Menengah. Tesis Dr. Fal., Fakulti Pendidikan, Universiti Kebangsaan Malaysia, Bangi.

Zohar, A., Degani, A., \& Vaaknin, E. (2001). Teachers' beliefs about low achieving students and higher order thinking. Teaching and Teacher Education, 17: 469-485.

Zohar, A., Degani, A., \& Vaaknin, E. (2001). Teachers' beliefs about low achieving students and higher order thinking. Teaching and Teacher Education, 17: 469-485. 